Manuscript Title:

\title{
Analyzing consumer-related nitrogen flows: A case study on food and
} material use in Austria

Authors: Magdalena Pierer ${ }^{a, *}$, Andrea Schröck $^{a}$, Wilfried Winiwarter $^{b}$

a Institute of Systems Sciences, Innovation and Sustainability Research, University of Graz, Merangasse 18, 8010 Graz, Austria

b International Institute for Applied Systems Analysis (IIASA), Schlossplatz 1, 2361 Laxenburg, Austria

* corresponding author at: Merangasse 18, 8010 Graz, Austria. E-mail: magdalena.pierer@edu.unigraz.at. Tel.: +43 (0)316 $380-7340$ 


\section{Analyzing consumer-related nitrogen flows: A case study on food and}

\section{2 material use in Austria}

\section{Abstract}

4 Nitrogen budgets cover pools and flows of nitrogen $(\mathrm{N})$ contained in human-made goods and

5 compounds, which may potentially affect the global nitrogen cycle and in consequence the human environment. Acknowledging the importance of food and other agricultural products, this paper additionally investigates frequently neglected flows of $\mathrm{N}$ related to consumers and estimates their magnitude, using Austria in 2010 as an example. Specifically, $\mathbf{N}$ in non-food industrial products (synthetic \& natural polymers, wood \& paper products, waste), and $\mathrm{N}$ related to pets, gardens, and energy use is considered. Over the last five decades, both food and material consumption have increased distinctly. While food supply accounts for $52 \%$ of total directly consumer-related nitrogen inflows covered in this study (66 $000 \mathrm{t} \mathrm{N} \mathrm{a}^{-1}$ ), also material products account for a considerable share of $28 \%\left(36000 \mathrm{t} \mathrm{N} \mathrm{a}^{-1}\right)$. $\mathrm{N}$ application in gardens (12\%) and $\mathrm{N}$ in pet food $(7 \%)$ do also play a role. Quantified outflows are human excretion (54\%), food waste (13\%), garden waste (16\%), material waste $(7 \%)$ and waste from pets (10\%). The detected balance surplus of $34000 \mathrm{t} \mathrm{N} \mathrm{a}^{-1}$, corresponding to $27 \%$ of total inflows, points to some accumulation of $\mathrm{N}$ in the form of durable consumer goods and to potentially missing flows. The analysis focusses on the apparent knowledge gaps. Especially flows involving material products are poorly understood and would require better understanding of nitrogen contents of products and of waste. This indicates that improvements may be possible by providing more complete nitrogen budgets in the future that cover all environmental pools.

Keywords: nitrogen budget, consumers, food, material products 


\section{Introduction}

Human influence has notably altered the complex natural nitrogen $(\mathrm{N})$ cycle. Over the course of the last century, the widespread use of Haber-Bosch synthesis significantly increased the amount of fixed nitrogen available for human use, mainly as fertilizer for food production. However, nitrogen is not only necessary and beneficial, but also has problematic effects on the environment and human health (see e.g. Erisman et al. (2013) and van Grinsven et al. (2013) for recent overviews).

Nitrogen budgets are tools to quantify and trace both natural and human-induced flows of nitrogen through a variety of systems, e.g. on global, regional or national scope, for economic sectors, single farms, households or watersheds (Leip et al. 2011b; UN ECE 2013). Anthropogenic flows are to a large extent connected to agricultural production and trade of food and feed, and fuel combustion. These human-induced flows have been estimated to be in the same order of magnitude as natural flows with the prospect of further increase. E.g., Galloway et al. (2004) assume that global anthropogenic $\mathrm{N}$ creation will be increasing from $156 \mathrm{Tg} \mathrm{N} \mathrm{a}^{-1}$ in the early $1990 \mathrm{~s}$ to $267 \mathrm{Tg} \mathrm{N} \mathrm{a}^{-1}$ in 2050, while total natural creation is to decrease from $233 \mathrm{Tg} \mathrm{N}^{-1}$ to $224 \mathrm{Tg} \mathrm{N} \mathrm{a}^{-1}$ in the same period. Consequently, many existing national nitrogen budgets focus on these agricultural and energyrelated aspects, e.g. van Egmond et al. (2002) for Europe, Olsthoorn and Fong (1998) for the Netherlands, Howarth et al. (2002) for the USA. More recent work includes Leip et al. (2011a) and Lassaletta et al. (2014), or Saikku et al. (2007) with a focus on energy. Ways to reduce the excess release of $\mathrm{N}$ compounds to the environment have been discussed extensively and include technical measures and adapted agricultural practices for a more nitrogen-efficient agricultural production (Spiertz 2010; Sutton et al. 2011; van Egmond et al. 2002). On the consumption side, many authors suggest shifts in diets (i.e., a reduction of animal-based foods) as well as the substantial reduction of food waste, especially in the developed world (Smil 2002; van Egmond et al. 2002). While considered to address nitrogen pollution, these measures would also be beneficial to other environmentally relevant issues, such as energy consumption, land use or greenhouse gas emissions (Stehfest et al. 2013). 
However, there are indications that apart from food and energy related flows, other $\mathrm{N}$ flows might also be relevant (Gu et al. 2012, 2013; Leip et al. 2011a). According to Leip et al. (2011a), more than $50 \%$ of the (reactive) $\mathrm{N}$ that is available for consumers serves other purposes than human nutrition, mostly in the form of non-food industrial products, but also forest products and pet food. These aspects have largely been neglected in national nitrogen budgets so far, mainly due to the lack of robust and consistent data. In addition, it has been argued that these flows are small in comparison and remain within the margins of uncertainty. The respective $\mathrm{N}$ is mostly incorporated in products and can thus be considered less critical with regard to environmental impacts and societal costs. While it is true that the $\mathrm{N}$ is bound in these products during most of their product lifetime and accumulates in human settlements, it may still become environmentally relevant when the products are disposed of (Houlton et al. 2013). The fate of this industrial N, however, remains unclear and poorly investigated (Galloway et al. 2008).

In a comprehensive study of carbon, nitrogen and phosphorus fluxes related to households, Fissore et al. (2011) did not only investigate transportation, landscape management, human diet and home energy use, but also included the less commonly used aspects of pet diet as well as detergents, paper and plastics. For the latter two, however, only carbon contents were assessed. Olsthoorn and Fong (1998) mention $\mathrm{N}$ flows in raw materials for the production of plastics, nylon and other synthetic materials, but do not discuss that further. They simply state the accumulation of $\mathrm{N}$ in durable, mostly synthetic, products and assess statistical errors as a balancing item in their national nitrogen balance.

While food- and energy-related $\mathrm{N}$ flows have thus been analyzed thoroughly, there is a clear lack of knowledge concerning other anthropogenic $\mathrm{N}$ flows, especially with regard to consumers. Demand from consumers is the central driving force behind all production activities. Consumption choices, consumer behavior and lifestyle determine not only $\mathrm{N}$ flows, but all kinds of material throughput through the anthroposphere (Brunner and Rechberger 2004; Fissore et al. 2011). Only when all potentially relevant flows of $\mathrm{N}$ have been quantified in a consistent way, a focus on certain aspects (with regard to environmental/consumer policy) can be justified (Brunner and Rechberger 2004). 
Against this background, we aim to systematically identify relevant $\mathrm{N}$ flows caused and influenced by consumers in order to trace pathways of $\mathrm{N}$ in a more complete way. Based on the principles of substance flow analysis, we provide quantitative estimates on the magnitude of these flows, using Austria as an example. Ultimately, this can serve to inform policy decisions and provide a better knowledge base on whether the current focus on food and agriculture is justified, or whether an extended perspective is needed (Leip et al. 2011a).

\section{Materials and Methods}

\subsection{Boundaries \& theoretical background}

The geographic boundaries of the system under analysis are the national borders of Austria, with 2010 as the principal year of analysis. For food-related flows the available data also allowed for an analysis of historic flows back until the 1960 's. For material flows, an estimation of the past can be given based on available timelines from material flow accounting in Austria (Petrovic 2014).

In contrast to life cycle or footprint analysis, where all flows along the entire lifetime of a product or good are considered, in this analysis only the nitrogen that is directly contained in the respective item is covered. This is among others due to the broad scope of the study. However, it is of relevance to compare the results with the total impacts related to a product as given for instance by nitrogen footprints (e.g. Pierer et al. 2014).

Commonly with nitrogen budgets, the system under analysis is separated into different compartments or pools. For national nitrogen budgets (NNB), the UN ECE (2013) recommends to distinguish eight pools: energy and fuels; material and products in industry; humans and settlements; agriculture; forest and semi-natural vegetation including soils; waste; atmosphere; hydrosphere. Instead of providing such a "traditional" complete nitrogen budget (Leip et al. 2011b; UN ECE 2013), we zoom in and focus on the consumer part, which largely corresponds to the pool "humans and settlements". This includes first of all food (diets \& food waste) and material products available for 
consumption that accumulate in the consumer sphere or are disposed of (synthetic polymers for product use, detergents, textiles, wearing apparel \& leather, wood \& paper products, tobacco). Furthermore, nitrogen flows related to animals not covered in agricultural statistics are also included (i.e. "standard" pets such as cats, dogs, small mammals etc., but also non-agricultural pleasure riding horses). Finally, as an integral part of human settlements and in accordance with UN ECE (2013), private gardens and public green areas are also considered in this study. In all these cases, consumption patterns are the central driving forces for the surrounding activities. Thus it proved useful to extend the analysis towards energy and fuels in order to cover the full range of nitrogen related to consumers (even as, being covered by energy statistics, this aspect is considered separately by UN ECE 2013).

Nitrogen flows (in particular the release to air, soil and water) related directly to agricultural or industrial production of goods and services, atmospheric deposition etc. are not included in this study. Furthermore, we do not trace pathways of $\mathrm{N}$ flows outside the core consumer sphere, i.e. in this analysis the flows end at the stage of waste management, the hydrosphere, or the atmosphere. In the context of a complete national nitrogen budget, these upstream flows would be covered by the respective pools (i.e., agriculture, material and products in industry, waste management etc.). The consumption of services might also cause some $\mathrm{N}$ flows, mainly related to energy use. However, this aspect cannot be separated conceptually, and is implicitly included in household energy use.

We consider annual flows that account for more than $100 \mathrm{~g} \mathrm{~N}$ per inhabitant (thus about $850 \mathrm{t} \mathrm{N}$ for Austria in total) as relevant for a NNB. For this quantification, we also scrutinized and accounted for smaller flows.

The procedure applied is inspired by material flow analysis (Brunner and Rechberger 2004; Uihlein et al. 2006): First, we qualitatively identified products and processes that contain nitrogen and might be relevant, paying particular attention to non-food related flows. In a next step, we estimated mass flows and nitrogen concentrations. Finally, we derived $\mathrm{N}$ flows by combining the amount of goods 
and nitrogen contents, which allowed us to identify the most relevant flows. This was done in an iterative process, i.e. some flows that were included at first were then removed because of insignificance, such as nitrate in drinking water, pharmaceuticals, metals and ceramic products. Others that did not seem relevant at first sight were included. This particularly applies to wood and paper products, which contain $\mathrm{N}$ only in very small percentages, but become relevant due to the large amounts of products consumed. Ideally in this system, inflows correspond to outflows plus possible changes in stocks. While balance differences (i.e., differences between inflows and outflows) of $10 \%$ are considered commonly acceptable and insignificant for the conclusions (Brunner and Rechberger 2004), larger differences might indicate missing flows or stock changes.

\subsection{Data basis \& determination of $\mathbf{N}$ flows}

To determine the $\mathrm{N}$ flows, primarily appropriate statistics as well as scientific literature was used. Sometimes these sources had to be complemented with assumptions. Table A1 of the appendix provides an overview on the data sources, and Table $\mathrm{A} 2$ shows the $\mathrm{N}$ contents used.

For food products, quantities of food as reported by Statistics Austria and FAO (Statistik Austria 2012b; FAO 2014a, 2014b, 2014c) are multiplied with total N contents (based on Souci et al. 2008 and other $\mathrm{N}$ budgets such as Heldstab et al. 2010). All plant oils, as well as sugars and sweeteners are excluded from the analysis, as they usually do not contain any protein and only negligible amounts of non-protein N. Not all $\mathrm{N}$ available as food is actually consumed by humans, as significant amounts of food are wasted. The amount of food waste was determined from Austrian waste statistics (Umweltbundesamt 2012). While this contains a separately declared waste fraction called "food waste", also the fraction "biogenic waste" has been assigned to food waste. By contrast, green waste has been included in "green waste and garden waste". Furthermore, it has been estimated that an additional 1.5 million tonnes of material is potentially available for private composting (Umweltbundesamt 2012). This material consists of biodegradable kitchen waste, plant residues and biogenic waste from private gardens. As no indication on its composition is given, $50 \%$ have been 

assigned to green waste, and $50 \%$ to food waste. To determine $\mathrm{N}$ flows for all food-related waste, the average $\mathrm{N}$ content of all food products supplied in 2010 was used $(0.84 \%)$.

Assuming that adults do not accumulate significant amounts of $\mathrm{N}$ in their body, most of the $\mathrm{N}$ that is consumed as food needs to be excreted as well. This is either excrements going to the sewage system or directly to the hydrosphere for households that are not connected to the sewage system (about $6.1 \%$ of all households in Austria, BMLFUW 2012). The total incoming nitrogen load to municipal sewage treatment plants is reported regularly (BMLFUW 2012). Sutton et al. (2000) also quantified the amount of $\mathrm{N}$ released due to sweating and breathing in the form of $\mathrm{NH}_{3}$, which is specifically taken into consideration here. Population dynamics, i.e. children who still accumulate some $\mathrm{N}$ in their body mass, as well as the net change in population based on births, deaths and migration are not included in the analysis as these are natural processes not directly connected to consumption patterns, and are negligible in their $\mathrm{N}$ flows.

Pet food and pet waste is determined based on estimations on the number of pets in Austria (FEDIAF 2010), and protein requirements as given in feeding recommendations (Table A1). There is no specific information available on the extent to which feeding recommendations are followed. Overfeeding of pets as well as wastage of pet food might occur, but these aspects are taken into account via the uncertainty assessment. Animals considered are dogs, cats, ornamental birds, aquarium fish, small mammals, and pleasure riding horses. As no data on pet excretion is available, pet excretion and waste was set equal to inflows in the form of pet food, assuming that no significant accumulation of $\mathrm{N}$ occurs in the pets' bodies.

Egle et al. (2014) estimate that in Austria about 1-3\% of total mineral fertilizer use is dedicated to private gardens and public green spaces, while the rest is consumed by agriculture. They also assume that $20 \%$ of the available compost is applied as fertilizer in gardens. Average production of compost amounts to roughly $700000 \mathrm{t}$, and total $\mathrm{N}$ contents of compost range from 0.6 to $2.3 \%$ dry matter (BMLFUW 2010). The industrial production of compost and emissions of ammonia and nitrous oxides 
that might occur during the production process (Martínez-Blanco et al. 2010) take place in the sector waste management and therefore are outside the boundaries of this study. Besides these professionally produced and statistically covered amounts of compost, large amounts of garden waste and green waste are used for home composting. As mentioned above, a potential of roughly 1.5 million tonnes of such material for home composting has been estimated for 2010 (Umweltbundesamt 2012). In contrast to the industrial production of compost, home composting is a conceptual part of the consumer sphere. Consequently, the material available for home composting is included as outflow on the one hand, and as inflow in the form of compost on the other hand. $\mathrm{N}$ losses in terms of ammonia and nitrous oxide emissions during the home composting process are accounted for (Colón et al. 2010).

Data on $\mathrm{N}$ embedded in non-food material products is particularly scarce. For textiles \& leather products, wood and tobacco, the assessment is based on production and foreign trade statistics (FAO 2014a, 2014b, 2014c; Statistik Austria 2012a) and approximated N contents of the respective products (Table A2). Consumption of paper was determined based on industry reports (Austropapier 2013), as the production of paper from recycled material could not be reliably estimated with production and foreign trade statistics. With regard to synthetic polymers for product use, it is very challenging to identify relevant products and determine specific $\mathrm{N}$ contents due to the broad range of products composed of many different materials. Consequently, $\mathrm{N}$ flows had to be estimated based on industry market reports of the basic substances polyamide, polyurethane and melamine in Europe, broken down into the share for Austria (Table A3).

Material waste can be approximated by utilizing waste statistics such as those included in the federal waste management plan (Umweltbundesamt 2012), although determination of $\mathrm{N}$ contents remains problematic, particularly for aggregated waste fractions such as residual or bulky waste. As an alternative approximation, Gu et al. (2013) estimate that roughly $25 \%$ of yearly inflows of industrial products accumulate in settlements (i.e. consumer durables that are used for more than one year). 
With regard to energy, only the outputs, i.e. the emissions of $\mathrm{NO}_{x}$ and $\mathrm{N}_{2} \mathrm{O}$ are considered. These are derived by applying average emission factors to the total energy use by households. In combustion processes, mainly two forms of $\mathrm{NO}_{x}$ are created: "new" reactive $\mathrm{N}$ from the fixation of atmospheric $\mathrm{N}_{2}$ in the combustion air, and mobilization of existing reactive $\mathrm{N}$ contained in the fuels (Galloway et al. 2004; Moomaw 2002). Most of the fuel nitrogen, however, is converted to unreactive $\mathrm{N}_{2}$ (Saikku et al. 2007). This explains why it is frequently assumed that all $\mathrm{NO}_{\mathrm{x}}$ emissions from combustion stem from fixation of atmospheric $\mathrm{N}_{2}$ only, rather than from the fuels per se (van Egmond et al. 2002). Due to these complex interactions and the role of unreactive $N_{2}$, it is impossible to establish a balance of inputs and outputs based on reactive $\mathrm{N}$ only, and no additional knowledge could be gained by including $\mathrm{N}_{2}$ in the system. As a consequence, the flow of $\mathrm{N}$ emissions due to energy use is treated separately and outside the balance of the other flows.

\subsection{Uncertainty assessment}

Due to the lack of established and consistent data sources and the range of necessary assumptions, the uncertainties related to the presented nitrogen flows are generally high. Where possible, we used different calculation approaches for the same flow to compare and validate the results (e.g. for food supply and wood \& paper products, as described above). Furthermore, most in- and outflows could be determined independently from each other, with the exception of pets, where excretion was set equal to food supply. This procedure allows largely independent validation of the results.

However, uncertainty assessment is needed in order to estimate the range of variation of the flows. As elaborate stochastic modelling and statistical analysis is not applicable to the available data, uncertainty levels are being used to allow at least indicative quantification. In analogy to Hedbrant and Sörme (2001), we assigned the data to a set of four uncertainty levels and the respective uncertainty factors (UF, see Table 1$)^{1}$. Whereas this approach originally has been developed in the context of urban heavy-metal metabolism, it was also used for Austrian national nutrient balances,

\footnotetext{
${ }^{1}$ These factors are also compatible with the ratings and typical error ranges from the EMEP/EEA air pollutant emission inventory guidebook 2013 (European Environment Agency 2013).
} 
224 flow, the uncertainty interval can be derived by both multiplying and dividing by the respective uncertainty factor.

Table 1: Levels of uncertainty (based on Hedbrant and Sörme 2001, Egle et al. 2014)

\begin{tabular}{|c|c|l|}
\hline Level & $\begin{array}{c}\text { Uncertainty } \\
\text { Factor (UF) }\end{array}$ & \multicolumn{1}{c|}{ Application } \\
\hline 1 & 1.1 & current official statistics, measurement data, data from appropriate literature \\
\hline 2 & 1.33 & $\begin{array}{l}\text { expert estimates, outdated official statistics, unofficial statistics, presentations, } \\
\text { industry reports }\end{array}$ \\
\hline 3 & 2.0 & $\begin{array}{l}\text { assumptions for which neither official statistics nor expert estimates were available } \\
\text { often based on based on on-line data sources or publications without accurate } \\
\text { literature reference }\end{array}$ \\
\hline 4 & 4.0 & an estimate based on a calculation derived from assumptions only \\
\hline
\end{tabular}

\section{Results and Discussion}

The main directly consumer-related $\mathrm{N}$ flows that have been quantified in this study for Austria in 2010 are summarized in Table 2. Total inflows of $\mathrm{N}$ to the consumer sphere amount to $126713 \mathrm{t} \mathrm{N}$ (with uncertainty estimates ranging from 99000 to $171000 \mathrm{t} \mathrm{N}$ ), and consist of food supply (52\%), material products (28\%), $\mathrm{N}$ application in gardens $(12 \%)$ and in pet food $(7 \%$, differences in total due to rounding). Total outflows amount to 92789 t N (with uncertainty estimates ranging from 64000 to $138000 \mathrm{t} \mathrm{N}), 54 \%$ of which are attributed to human excretion and $13 \%$ to food waste. Also garden waste $(16 \%)$, material waste $(7 \%)$ and waste from pets $(10 \%)$ contribute, with the latter estimated just from the inflows of pet food consumed. Considering the sum of all flows, there are more inflows than outflows accounted for. Overall, the balance difference (surplus) of $33924 \mathrm{t} N$ corresponds to $27 \%$ of total inflows. As discussed in more detail below, this difference is assumed to be caused by flows that might have been missed in the analysis (mainly material products, but also human body excretion), or by accumulation of $\mathrm{N}$ in the form of durable consumer goods. Energy is not included in the balance calculation, but with roughly $30000 \mathrm{t} \mathrm{N} \mathrm{a}^{-1}$ constitutes a significant amount of reactive $\mathrm{N}$

242 that is emitted to the atmosphere. 
243 The following flows turned out to be likely irrelevant: (i) Products from semi-natural vegetation, such 244 as cut flowers; these could not be quantified separately due to data problems, but in a full NNB, at 245 least their fertilization would be accounted for within the compartment of agriculture; (ii) metal and 246 ceramic products, which typically contain very little $\mathrm{N}(\mathrm{N}<0.1 \%)$; (iii) nitrate in drinking water and 247 food: according to Elmadfa and Burger (1999), an average person in Austria takes in about $69 \mathrm{mg}$ of 248 nitrate per day in drinking water and food, which sums up to only $50 \mathrm{t} \mathrm{NO}_{3}-\mathrm{N}$ for Austria as a whole in 2492010 , and even less for drinking water alone. 
Table 2: Quantified consumer-related N flows in Austria 2010. UF = uncertainty factor; where no UF is presented, $\mathrm{N}$ min and $\mathrm{N}$ max are estimated in a simplified manner as the sum of $\mathrm{N}$ min and $\mathrm{N}$ max of the respective elements.

\begin{tabular}{|c|c|c|c|c|c|c|c|c|c|}
\hline Inflows & $\begin{array}{l}\mathrm{N} \text { flow } \\
{\left[\mathrm{t} \mathrm{N} \mathrm{a}^{-1}\right]}\end{array}$ & UF & $\begin{array}{l}\mathrm{N} \min \\
{\left[\mathrm{t} \mathrm{N} \mathrm{a}^{-1}\right]}\end{array}$ & $\begin{array}{l}\mathrm{N} \max \\
{\left[\mathrm{t} \mathrm{N} \mathrm{a}^{-1}\right]}\end{array}$ & Outflows & $\begin{array}{l}\mathrm{N} \text { flow } \\
{\left[\mathrm{t} \mathrm{N} \mathrm{a}^{-1}\right]}\end{array}$ & UF & $\begin{array}{l}\mathrm{N} \min \\
{\left[\mathrm{t} \mathrm{N} \mathrm{a}^{-1}\right]}\end{array}$ & $\begin{array}{l}\mathrm{N} \max \\
{\left[\mathrm{t} \mathrm{N} \mathrm{a}{ }^{-1}\right]}\end{array}$ \\
\hline Food supply & 66155 & & 60141 & 72770 & Food waste & 11922 & 1.33 & 8964 & 15856 \\
\hline Animal food domestic & 20700 & 1.1 & 18818 & 22770 & & & & & \\
\hline Animal food from imports & 15868 & 1.1 & 14425 & 17455 & Human Body Excretion & 50424 & & 41572 & 74261 \\
\hline Plant food domestic & 18694 & 1.1 & 16995 & 20563 & Human excretion to sewage system & 47157 & 1.33 & 38531 & 68158 \\
\hline \multirow[t]{2}{*}{ Plant food from imports } & 10894 & 1.1 & 9903 & 11983 & Human excretion to hydrosphere & 3063 & 1.33 & 2989 & 5288 \\
\hline & & & & & Atmospheric emissions human body & 204 & 4.0 & 51 & 815 \\
\hline Material Products & 35518 & & 23509 & 55837 & Material waste & 6046 & 2 & 3023 & 12091 \\
\hline Synthetic polymers for product use & 11865 & 2 & 5932 & 23729 & & & & & \\
\hline Detergents & 73 & 4 & 18 & 290 & & & & & \\
\hline Textiles, Wearing apparel \& Leather & 9437 & 1.33 & 7095 & 12551 & & & & & \\
\hline Wood \& paper products & 13464 & 1.33 & 10123 & 17907 & & & & & \\
\hline Tobacco & 680 & 2 & 340 & 1360 & & & & & \\
\hline Pet food supply ( $\&$ consumption) & 9355 & 1.33 & 7034 & 12443 & Waste $\&$ excretion from pets ${ }^{*}$ & 9355 & 1.33 & 7034 & 12443 \\
\hline $\begin{array}{l}\mathbf{N} \text { input to private gardens \& public } \\
\text { green spaces }\end{array}$ & 15685 & & 8386 & 29922 & Green waste \& garden waste & 15042 & 2 & 7521 & 30083 \\
\hline Mineral fertilizer & 2160 & 1.33 & 1624 & 2873 & & & & & \\
\hline Compost & 13525 & 2 & 6762 & 27050 & & & & & \\
\hline \multirow[t]{6}{*}{ Total Inflows } & 126713 & & 99070 & 170973 & Total Outflows & 92789 & & 64352 & 138082 \\
\hline & & & & & $\mathrm{N}$ balance (inflows - outflows) & 33924 & & 34718 & 32891 \\
\hline & & & & & Energy & 30075 & & 22613 & 40000 \\
\hline & & & & & Heating & 2997 & 1.33 & 2253 & 3986 \\
\hline & & & & & Electricity & 898 & 1.33 & 675 & 1194 \\
\hline & & & & & Transportation & 26180 & 1.33 & 19684 & 34820 \\
\hline
\end{tabular}


Food. The most straightforward and uncritical aspect of this study are nitrogen flows related to food.

254 Data on food supply (rather than actual food consumption) are readily available from reliable sources

255 (Statistics Austria and FAO) back until the 1960's. Minor differences were detected comparing the food amounts reported by Statistics Austria and FAO over the time periods, possibly as a result of errors in data transmission (e.g., FAO reports distinctly higher amounts of pork supply compared to Statistics Austria - roughly 580000 t vs. 470000 t in 2010, respectively). Overall, however, the data match, and we used the FAO figures due to their consistent reporting format. However, we could not rely on protein supply data by commodity, which is reported by FAO in addition to mere food supply data. Here FAO statistics appear inconsistent: $\mathrm{N}$ flows derived from food supply data multiplied by respective protein content are about 35\% (for vegetables) and 10-15\% (for animal products) higher compared to flows derived from protein supply data. This is a consequence of the reporting format which issues zero values for some minor food categories. Thus we refer to FAO's food supply statistics and the relevant protein contents only. The time trend (Figure 1) confirms observations of other studies (e.g., Lassaletta et al. 2014; Liu et al. 2014): Over time, the share of animal N supply has increased from roughly $47 \%$ in 1961 to $55 \%$ in 2010 . Absolute amounts of total $\mathrm{N}$ supply have increased from 47929 t N in 1961 (22 367 t N from animals, 25562 t N from plants) to 66155 t N in 2010 (36 567 t N from animals, 29588 t N from plants). On a per capita basis, the supply of vegetable $\mathrm{N}$ has decreased slightly from 1961 to 2010 (minus 2\%), while the animal N supply has increased by $39 \%$. These figures do not, however, show the losses of nitrogen that occur during agricultural production and processing of the food, or the food waste on the consumer side. These aspects are covered by footprints, such as presented by Pierer et al. (2014) who calculated "virtual nitrogen factors" (VNF) for Austria that give the losses of reactive $\mathrm{N}$ along the entire production and consumption chain per $\mathrm{kg} \mathrm{N}$ consumed as a final food item. Applying these virtual nitrogen factors

276 (Pierer et al. 2014) to our results on total food consumption implies a total loss of nearly $150000 \mathrm{t} \mathrm{N}$

277 for Austria in 2010. Dividing this amount by the $\mathrm{N}$ actually consumed indicates that on average, for 
each $\mathrm{kg}$ of $\mathrm{N}$ directly consumed as food, an additional $1.8 \mathrm{~kg}$ of $\mathrm{N}$ are lost to the environment during production and processing.

Food waste in our study is estimated as $11922 \mathrm{t} \mathrm{N}$ in 2010, which matches the estimates for Austria presented by Gustavsson et al. (2011): 11833 t N a $\mathrm{a}^{-1}$; and Monier et al. (2010): $9672 \mathrm{t} \mathrm{N}$ from wholesale and retail, households, food services and restaurants based on national studies; or $9743 \mathrm{t}$ $\mathrm{N}$ from households and other sectors based on Eurostat estimates for 2006. The relatively large amount of food waste - corresponding to $13 \%$ of the quantified outflows - points to a readily attainable potential of reducing $\mathrm{N}$ loss. Avoiding food waste is an issue of growing concern and public awareness as illustrated by current scientific publications and public campaigns both in Austria (BMLFUW 2015) and internationally (European Commission 2015; Grizzetti et al. 2013; Gustavsson et al. 2011).

Human Excretion. Total excretion from the human body adds up to $50424 \mathrm{t} \mathrm{N}$, the dominating share of which enters the sewage system (93.5\% of total human body excretion). $\mathrm{N}$ excreted by humans that flows directly to the hydrosphere because of missing connections to the sewage system is of minor importance (6.1\% of total) - sewage connection rates in Austria are considered high (BMLFUW 2012). Atmospheric emissions of ammonia $\left(\mathrm{NH}_{3}\right)$ as determined according to Sutton et al. (2000) are listed separately here for reasons of completeness, but are insignificant ( $0.4 \%$ of total). Comparing human excretion with the amount of $\mathrm{N}$ from food that is available for consumption (i.e., food supply minus food waste, $54233 \mathrm{t} \mathrm{N}$ ) shows that roughly $4000 \mathrm{t} \mathrm{N}$ of outflows are "missing". This corresponds to $7 \%$ of the inflows and seems to be an acceptable discrepancy. A possible explanation for this balance difference could be detected on the side of the inflows: It is conceivable that the amounts of food waste are underestimated, as food waste is very difficult to capture statistically. Higher amounts of food waste would reduce the amount of food available for consumption and consequently shrink the gap between food consumption and human excretion. 
Material Products. The main area of balance differences is non-food industrial products: Inflows of material products amount to $35518 \mathrm{t} \mathrm{N}$, but material waste is only $6046 \mathrm{t} \mathrm{N}$, which gives a mismatch of $29472 \mathrm{t} \mathrm{N}$ (or $83 \%$ of inflows). Thus, the amount of $\mathrm{N}$ in material waste from waste statistics covers only roughly $17 \%$ of estimated material inflows, which is considerably less than the $75 \%$ assumed by Gu et al. (2013). Uncertainties related to this estimate are high, but cannot fully account for the detected difference, as the covered total waste streams are smaller than any one of the three main material classes covered as inflows. This indicates that besides stock changes (i.e., accumulation of material products in human settlements), there must exist residual waste streams which are not covered by the method applied. Residual waste streams are likely to include waste that is not accounted for in the waste statistics and/or not directly assigned to households, e.g. end-of-life vehicles which contain synthetic polymers, the $\mathrm{N}$ content of which cannot be estimated reliably on the waste side. Furthermore, there might be a certain fraction of material products that have been incorrectly assigned as inflows to households rather than industry, and the respective outflows would have to be found in statistics on industrial waste (e.g., polymers that are used for the construction of manufacturing machines rather than consumer goods). Statistical information that clearly distinguishes between material use by households and industries is scarce. However, additional data collection endeavors at this level of detail will be useful only if the information gained can also be used for other purposes besides $\mathrm{N}$ budgets. For many (scientific) questions, the existing material flow accounting may be sufficient (Fischer-Kowalski et al. 2011).

With regard to the inflows of material products, our results translate to $4.2 \mathrm{~kg} \mathrm{~N} \mathrm{cap}^{-1} \mathrm{a}^{-1}$ (ranging between 2.8 and $6.7 \mathrm{~kg}$ ). This corresponds well with Obernosterer and Reiner (2003), who used a different approach but estimated $\mathrm{N}$ flows of between 3.7 and $6 \mathrm{~kg} \mathrm{~N} \mathrm{cap}^{-1} \mathrm{a}^{-1}$ for durable consumer goods such as furnishing and $0.6-1 \mathrm{~kg} \mathrm{~N} \mathrm{cap}^{-1} \mathrm{a}^{-1}$ for non-durable consumable goods such as packaging and detergents.

Pets. $\mathrm{N}$ inflows as pet food have been assumed as a separate flow quantified based on protein requirements and feeding recommendations. It might be argued that pet food partly stems from 
human food (or human food waste), which would reduce the $\mathrm{N}$ food supply and thus lower the

329 amount of total inflows for the balance. However this problem can be neglected, as the amount of $\mathrm{N}$

330 from pet food is in the same order of magnitude as the margins of uncertainty for food supply. Waste and excretion from pets could not be quantified independently, and was set to match with pet food supply.

Within the sphere of private gardens and public green spaces, the independently determined outflows (i.e., green waste and garden waste based on waste statistics) do match well with the inflows (i.e., mineral fertilizer and compost). A potentially missing outflow, however, is food harvested from private gardens, which cannot be included due to lacking data, and is assumed to be small.

Temporal trend. Figure 1 shows the development of nitrogen flows related to food supply in Austria from 1961 to 2010. This corresponds to food consumption and food waste by Austrian consumers from both domestic production and imports. It does not include food exports, which are not relevant

341 for consumption. Figure 2 combines this time trend of food supply $\mathrm{N}$ with trends of total material

342 consumption. As no information on historical material $\mathrm{N}$ contents and flows is available, only the trend of total domestic material consumption as assessed by standard material flow accounts (Petrovic 2014) is shown, which not necessarily fully reflects trends of $\mathrm{N}$ contained in such material. Furthermore, it has to be considered that "domestic consumption" in material flow accounting includes the use of different natural resources, but does not directly correspond to material consumption by consumers or households. Still, the trends for food and materials (Figure 2) indicate 


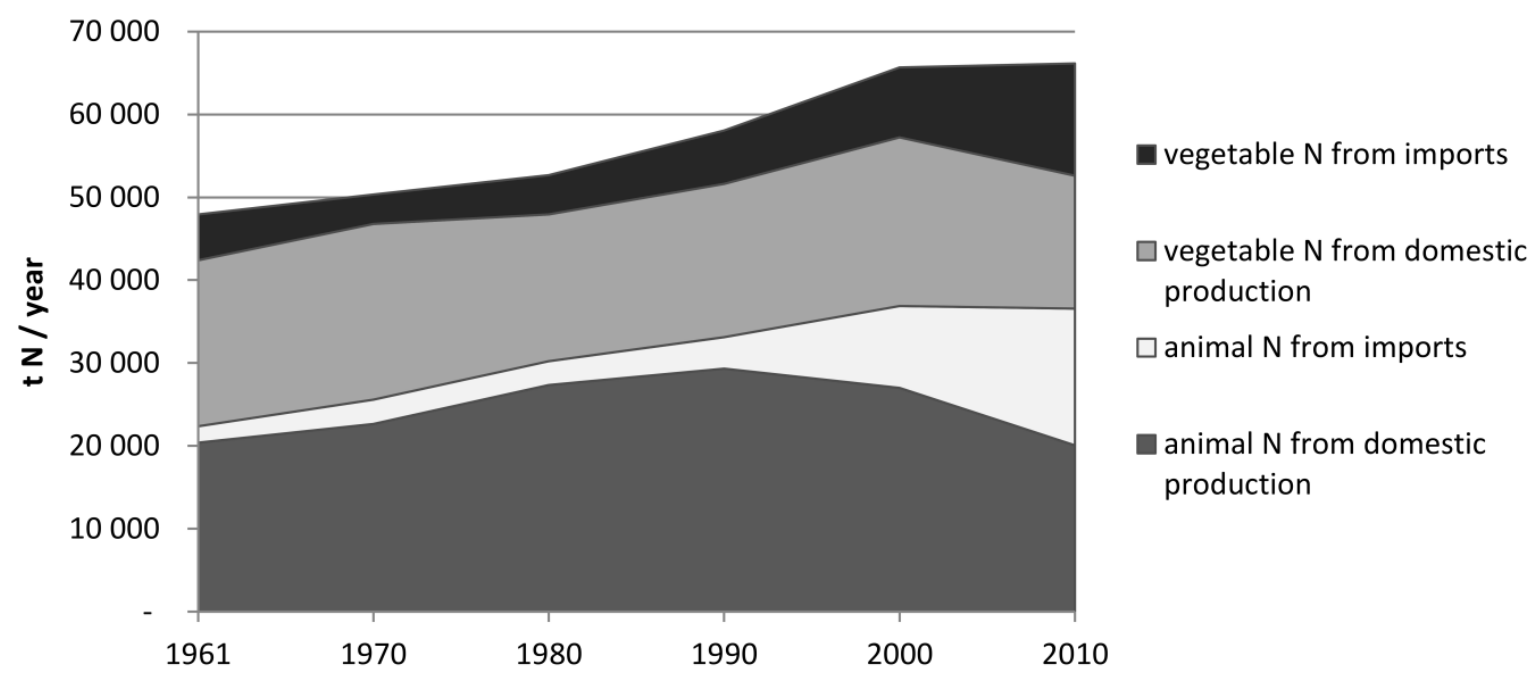

351 Figure 1: Development of food N supply in Austria: 1961 - 2010, corresponding to food consumption and food waste from

352 domestic production and imports, respectively. (Source: own calculation based on FAO 2014a, 2014b, 2014c; Statistik Austria 2012b)

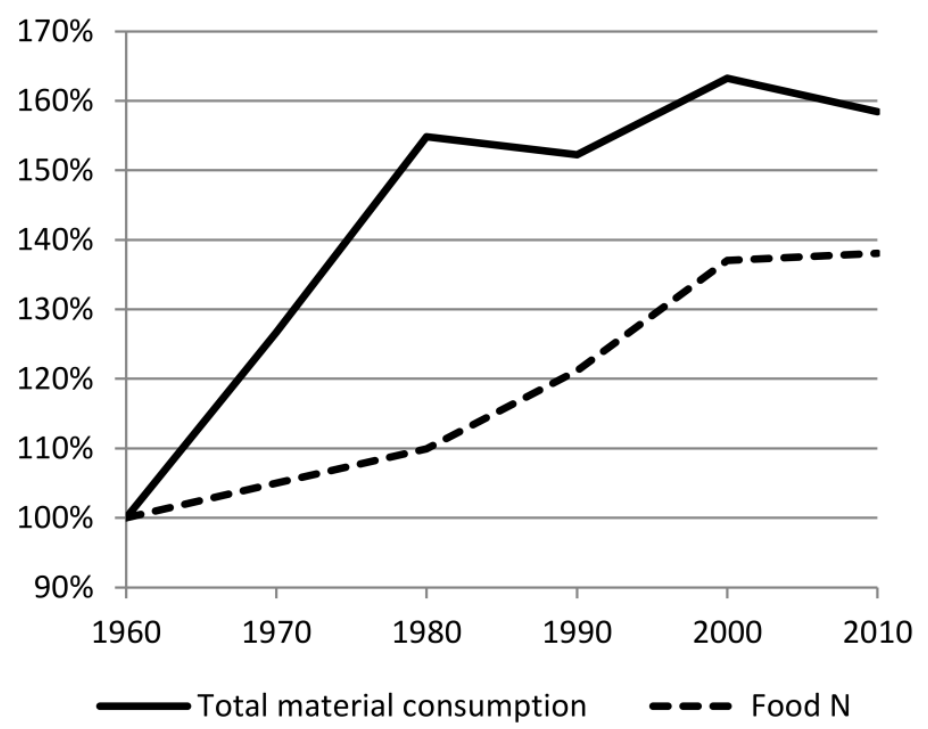

Figure 2: Temporal trends of food $\mathbf{N}$ and total material flows, representing $\mathbf{N}$ in materials. $100 \%=1960$. (Food: own calculations based on Statistik Austria 2012b; FAO 2014a, 2014b, 2014c. Materials: based on trends from material flow accounting (Petrovic 2014 - without direct reference to nitrogen contents.)

359 The present analysis provides a budget of $\mathrm{N}$ flows related to consumers in Austria. Detailed scrutinizing of otherwise under-represented and poorly investigated aspects reveals the importance 
of $\mathrm{N}$ flows related to material products, private gardens and public green spaces, as well as pets. $\mathrm{N}$ flows related to food are rather well constrained and remain the single most important item within the boundaries of this analysis. Comparing independent datasets of flows in and out of the consumer sphere helps to support the available data and improves their reliability.

Valuable information can also be drawn from an observed discrepancy, pointing to a knowledge gap within national nitrogen budgets: With regard to material products, our results indicate unaccounted streams of material waste, or an unexplained stock change. Here the present data is not sufficient to fully explain the fate of N. In general, this proves that the systematic consideration of such flows in nitrogen budgets makes sense and should be pursued.

The knowledge gap regarding material products not only refers to the quantities, but also to the chemical form of the substances involved. Potentially, the environmental relevance of the missing $\mathrm{N}$ flows is very limited, as $\mathrm{N}$ may be enclosed in a stable form and not become environmentally active. Additional scrutiny will be needed to better understand the missing quantity and quality of $\mathrm{N}$ flows. This may be achieved by a look at the broader system, i.e. the connection between the segment analyzed here and the other "pools" of a nitrogen budget on a national basis (UN ECE 2013).

\section{Acknowledgements}

This paper has been developed for and with the help of the Expert Panel on Nitrogen Budgets operating under the UNECE Task Force on Reactive Nitrogen. It contributes to the International Nitrogen Initiative and has received support from the ÉCLAIRE project. We acknowledge a scholarship received from the University of Graz.

\section{Appendix}

Table A 1: Overview on main data sources used to determine mass flows

\begin{tabular}{|l|l|}
\hline Flow & Main data sources \\
\hline Food supply & Statistik Austria 2012b, FAO 2014a, 2014b \\
\hline Food consumption, food waste & Umweltbundesamt 2012 \\
\hline Synthetic polymers for product use & ISOPA 2003, Plastemart 2007a, 2007b, IHS chemical sales 2010; \\
\hline
\end{tabular}




\begin{tabular}{|l|l|}
\hline & OCI Nitrogen 2011; Raimar 2012 \\
\hline Wood \& paper & Statistik Austria 2012a; Austropapier 2013; FAO 2014c \\
\hline Textiles \& leather & Statistik Austria 2012a; FAO 2014c \\
\hline Detergents \& surfactants & Statistik Austria 2012a \\
\hline Pet food, pet waste & $\begin{array}{l}\text { Sutton et al. 2000; Hand et al. 2002; Methling and Unshelm 2002; } \\
\text { Weiss et al. 2003; FEDIAF 2010; }\end{array}$ \\
\hline $\begin{array}{l}\text { Garden fertilizer, garden waste, } \\
\text { compost }\end{array}$ & $\begin{array}{l}\text { BMLFUW 2010; Umweltbundesamt 2012; Egle et al. 2014; } \\
\text { International Fertilizer Industry Association 2014; ARGE Kompost } \\
\text { \& Biogas Österreich 2014; Colón et al. 2010 }\end{array}$ \\
\hline N excretion \& emission by human body & Sutton et al. 2000; BMLFUW 2012 \\
\hline Energy & Statistik Austria 2011 \\
\hline
\end{tabular}

Table A 2: $\mathbf{N}$ contents of products and substances.

\begin{tabular}{|c|c|c|}
\hline Item & $\begin{array}{l}\mathbf{N} \\
\text { content } \\
{[\%]}\end{array}$ & Sources / Comments \\
\hline Food Products average total & 0.84 & \multirow{3}{*}{ Souci et al. 2008; Heldstab et al. 2010} \\
\hline Animal-based food average & 1.12 & \\
\hline Plant-based food average & 0.64 & \\
\hline Food Waste & 0.84 & approximated by the average of all food supply in 2010 \\
\hline \multicolumn{3}{|l|}{ Polymers } \\
\hline $\begin{array}{l}\text { Polyamide (nylon, PA66, }\left(\mathrm{C}_{6} \mathrm{H}_{11} \mathrm{NO}\right)_{n} ; \\
\left.\text { perlon, } \mathrm{PA6},\left(\mathrm{C}_{12} \mathrm{H}_{22} \mathrm{~N}_{2} \mathrm{O}_{2}\right)_{n}\right)\end{array}$ & 12 & stoichiometry \\
\hline Polyurethane (broad distribution) & 10 & estimate \\
\hline $\begin{array}{l}\text { Melamine (melamin formaldehyde, } \\
\left.\left(\mathrm{C}_{7} \mathrm{H}_{12} \mathrm{~N}_{6}\right)_{n}\right)\end{array}$ & 47 & stoichiometry \\
\hline Detergents (cationic surfactants) & 2.1 & $\begin{array}{l}\text { mass weight representative calculated based on an esterquat } \\
\text { (quaternary ammonium cations with a relative molecular } \\
\text { weight of } 648 \mathrm{~g} / \mathrm{mol} \text { ). }\end{array}$ \\
\hline \multicolumn{3}{|l|}{ Textiles \& Wearing apparel } \\
\hline made of crop fibers & 0.2 & $\begin{array}{l}\text { includes cotton, cellulose, flax, plush, velvet, fleece, chenille; } \\
\text { estimate for cotton based on Bode et al. } 2007\end{array}$ \\
\hline made of animal hair or animal fibers & 15 & $\begin{array}{l}\text { e.g. wool, silk, cashmere, fur, felt; these consist mainly of } \\
\text { fibroin, sericin, keratin, collagen which are mainly proteins } \\
\text { (assumption: } 95 \% \text { protein) }\end{array}$ \\
\hline leather and related products & 15 & $\begin{array}{l}\text { Consists mainly of collagen, with an assumed protein content } \\
\text { of } 95 \%\end{array}$ \\
\hline Wood and wood products & 0.1 & Leppälahti and Koljonen 1995; Heldstab et al. 2010 \\
\hline Paper and paper products & 0.1 & Leppälahti and Koljonen 1995; Heldstab et al. 2010 \\
\hline Tobacco & 4.0 & Butorac et al. 2004 \\
\hline Compost & $\begin{array}{l}1.45 \\
(0.6-2.3)\end{array}$ & BMLFUW 2010 \\
\hline Green Waste & 0.8 & Kumar et al. 2010; Vaughan et al. 2011 \\
\hline
\end{tabular}

Table A 3: Estimated consumption of Polyurethanes (PU), Polyamides (PA) and Melamine in 2010 (PU and Melamine) and 2007 (PA).

\begin{tabular}{|l|l|l|l|}
\hline & $\begin{array}{l}\text { Polyurethanes } \\
\text { (PU) }\end{array}$ & $\begin{array}{l}\text { Polyamides } \\
\text { (PA) }\end{array}$ & $\begin{array}{l}\text { Melamine/Urea } \\
\text { Formaldehyde Resins (MF, } \\
\text { MUF, UF) }\end{array}$ \\
\hline Demand worldwide [million t] & 14 & 7 & 1.2 \\
\hline Demand Europe [million t] & 5 & 3.08 & 0.384 \\
\hline Sources & Raimar 2012 & $\begin{array}{l}\text { Plastemart 2007a, } \\
2007 b\end{array}$ & $\begin{array}{l}\text { OCl Nitrogen 2011; IHS } \\
\text { chemical sales 2010 }\end{array}$ \\
\hline N Consumption Europe* & 676 & 499 & 244 \\
\hline
\end{tabular}




\begin{tabular}{|l|l|l|l|}
\hline [t N/million inhabitants] & & & \\
\hline N Consumption Austria [t N] & 5649 & 4176 & 2039 \\
\hline *) Own calculations, based on European population of 740 million; N content factors as given in Table A2 \\
\hline
\end{tabular}

\section{References}

ARGE Kompost \& Biogas Österreich 2014. Compost Statistics. Retrieved 29 Jul, 2014, from http://www.kompost-biogas.info/index.php?option=com_content\&task=view\&id=193\&ltemid=227

Austropapier 2013. The Annual Report of the Austrian Paper Industry 2013 (in German)

BMLFUW 2010. Guidelines for the use of compost from biogenic waste in agriculture (in German)

BMLFUW 2012. Council Directive 91/271/EEC concerning urban waste-water treatment. Austrian Report 2012 (in German)

BMLFUW 2015. Food is precious (in German). Retrieved 9 Apr, 2015, from http://www.bmlfuw.gv.at/land/lebensmittel/kostbare_lebensmittel.html

Bode, A., Hardt, P., Pöhling, M., Rauch, W., Schröder, V., Tausch, M.W., et al. 2007. Informationsserie Textilchemie. Fonds der Chemischen Industrie im Verband der Chemischen Industrie e.V., Frankfurt (Main) (Information on textile chemistry, in German)

Brunner, P.H., and Rechberger, H. 2004. Practical Handbook of Material Flow Analysis. CRC Press, Boca Raton, $\mathrm{FL}$

Butorac, A., Turšić, I., Mesić, M., Butorac, J., Bašić, F., Vuletić, N., et al. 2004. The effect of tobacco monoculture and crop rotation on tobacco leaf composition. Die Bodenkultur 55(3):129-134

Colón, J., Martínez-Blanco, J., Gabarrell, X., Artola, A., Sánchez, A., Rieradevall, J., Font, X. 2010. Environmental assessment of home composting. Resources, Conservation and Recycling 54(11):893-904

Egle, L., Zoboli, O., Thaler, S., Rechberger, H., and Zessner, M. 2014. The Austrian P budget as a basis for resource optimization. Resources, Conservation and Recycling 83:152-162

Elmadfa, I., and Burger, P. 1999. Expert report: food safety nitrate, Vienna

Erisman, J.W., Galloway, J.N., Seitzinger, S., Bleeker, A., Dise, N.B., Petrescu, R., Leach, A.M., and Vries, W. de 2013. Consequences of human modification of the global nitrogen cycle. Philosophical Transactions of the Royal Society B: Biological Sciences 368: 20130116.)

European Commission 2015. Food Waste. Website. Retrieved 9 Apr, 2015, from http://ec.europa.eu/food/safety/food_waste/index_en.htm

European Environment Agency 2013. EMEP/EEA air pollutant emission inventory guidebook 2013. Technical guidance to prepare national emission inventories, Luxembourg

FAO 2014a. FAO Food Supply Data. Crops Primary Equivalent. Retrieved 22 Sep, 2014, from http://faostat3.fao.org/faostat-gateway/go/to/download/FB/CC/E

FAO 2014b. FAO Food Supply Data. Livestock and Fish Primary Equivalent. Retrieved 22 Sep, 2014, from http://faostat3.fao.org/faostat-gateway/go/to/download/FB/CL/E

FAO 2014c. FAOSTAT Production Data. Retrieved 22 Sep, 2014, from http://faostat3.fao.org/faostatgateway/go/to/download/Q/*/E

FEDIAF 2010. Facts \& Figures 2010. FEDIAF - The European Pet Food Industry, Brussels. 
Fischer-Kowalski, M., Krausmann, F., Giljum, S., Lutter, S., Mayer, A., Bringezu, S., Moriguchi, Y., Schütz, H., et al. 2011. Methodology and Indicators of Economy-wide Material Flow Accounting. Journal of Industrial Ecology 15(6):855-876

Fissore, C., Baker, L.A., Hobbie, S.E., King, J.Y., McFadden, J.P., Nelson, K.C., and Jakobsdottir, I. 2011. Carbon, nitrogen, and phosphorus fluxes in household ecosystems in the Minneapolis-Saint Paul, Minnesota, urban region. Ecological Applications 21(3):619-639

Galloway, J.N., Dentener, F.J., Capone, D.G., Boyer, E.W., Howarth, R.W., Seitzinger, S.P., Asner, G.P., and Cleveland, C.C., et al. 2004. Nitrogen Cycles: Past, Present, and Future. Biogeochemistry 70(2):153-226

Galloway, J.N., Townsend, A.R., Erisman, J.W., Bekunda, M., Cai, Z., Freney, J.R., Martinelli, L.A., and Seitzinger, S.P., et al. 2008. Transformation of the Nitrogen Cycle: Recent Trends, Questions, and Potential Solutions. Science 320(5878):889-892

Grizzetti, B., Pretato, U., Lassaletta, L., Billen, G., and Garnier, J. 2013. The contribution of food waste to global and European nitrogen pollution. Environmental Science \& Policy 33: 186-195

Gu, B., Chang, J., Min, Y., Ge, Y., Zhu, Q., Galloway, J.N., and Peng, C. 2013. The role of industrial nitrogen in the global nitrogen biogeochemical cycle. Scientific Reports 3

Gu, B., Dong, X., Peng, C., Luo, W., Chang, J., and Ge, Y. 2012. The long-term impact of urbanization on nitrogen patterns and dynamics in Shanghai, China. Environmental Pollution 171:30-37

Gustavsson, J., Cederberg, C., and Sonesson, U. 2011. Global Food Losses and Food Waste. Extent, Causes and Prevention. FAO, Rome/Italy

Hand, M.S., Thatcher, C.D., Remillard, R.L., and Roudebush, P. 2002. Small Animal Clinical Nutrition, 4th edn. Mark Morris Institute, Topeka/Kansas

Hedbrant, J., and Sörme, L. 2001. Data vagueness and uncertainties in urban heavy-metal data collection. Water, Air, and Soil Pollution: Focus 1(3-4):43-53

Heldstab, J., Reutimann, J., Biedermann, R., and Leu, D. 2010. Nitrogen fluxes in Switzerland. A material flux analysis for the year 2005. Bundesamt für Umwelt, Bern (in German, English summary)

Houlton, B.Z., Boyer, E., Finzi, A., Galloway, J., Leach, A., Liptzin, D., Melillo, J., and Rosenstock, T.S., et al. 2013. Intentional versus unintentional nitrogen use in the United States: trends, efficiency and implications. Biogeochemistry 114(1-3):11-23

Howarth, R.W., Boyer, E.W., Pabich, W.J., and Galloway, J.N. 2002. Nitrogen Use in the United States from 1961-2000 and Potential Future Trends. Ambio 31(2):88-96

IHS chemical sales 2010. Melamine (Abstract). Retrieved April 2013, from http://www.ihs.com/products/chemical/planning/ceh/melamine.aspx

International Fertilizer Industry Association 2014. IFA Statistics - IFADATA. Retrieved 29 Jul, 2014, from http://ifadata.fertilizer.org/ucSearch.aspx

ISOPA 2003. Industry Data : Socio-economic information on the European Polyurethanes Industry. Retrieved April 2013, from http://www.isopa.org/isopa/index.php?page=useful-documents

Kumar, M., Ou, Y.-L., and Lin, J.-G. 2010. Co-composting of green waste and food waste at low C/N ratio. Waste Management 30(4):602-609

Lassaletta, L., Billen, G., Romero, E., Garnier, J., and Aguilera, E. 2014. How changes in diet and trade patterns have shaped the N cycle at the national scale: Spain (1961-2009). Regional Environmental Change 14(2):785-797 
Leip, A., Achermann, B., Billen, G., Bleeker, A., Bouwman, A.F., Vries, W. de, Dragosits, U., and Döring, U., et al. 2011a. Integrating nitrogen fluxes at the European scale. In: Sutton MA, Howard C, Erisman JW, Billen G, Bleeker A, Grennfelt P, van Grinsven H, Grizzetti B (eds) The European Nitrogen Assessment. Sources, Effects and Policy Perspectives. Cambridge University Press, Cambridge/UK, pp 345-376

Leip, A., Britz, W., Weiss, F., and Vries, W. de 2011b. Farm, land, and soil nitrogen budgets for agriculture in Europe calculated with CAPRI. Environmental Pollution 159(11):3243-3253

Leppälahti, J., and Koljonen, T. 1995. Nitrogen evolution from coal, peat and wood during gasification: Literature review. Fuel Processing Technology 43:1-45

Liu, C., Fei, J., Hayashi, Y., and Yasunari, T. 2014. Socioeconomic driving factors of nitrogen load from food consumption and preventive measures. Ambio 43(5):625-633

Martínez-Blanco, J., Colón, J., Gabarrell, X., Font, X., Sánchez, A., Artola, A., and Rieradevall, J. 2010. The use of life cycle assessment for the comparison of biowaste composting at home and full scale. Waste Management 30 (6):983-994

Methling, W., and Unshelm, J. 2002. Umwelt- und tiergerechte Haltung von Nutz-, Heim- und Begleittieren. Parey Buchverlag, Berlin (Environmentally sound and humane animal husbandry, in German)

Monier, V., Mudgal, S., Escalon, V., O'Connor, C., Gibon, T., Anderson, G., Montoux, H., and Reisinger, H., et al. 2010. Preparatory study on food waste across EU 27. Final Report. Technical Report

Moomaw, W.R. 2002. Energy, industry and nitrogen: strategies for decreasing reactive nitrogen emissions. Ambio 31(2):184-189

Obernosterer, R., and Reiner, I. 2003. "Nitrogen Budget Austria". Waste Management's contribution. Final Report Project ABASG II-N. Ressourcen Management Agentur, Villach (in German)

OCI Nitrogen 2011. Market data. Retrieved Juli 2014, from http://www.ocinitrogen.com/melamine/EN/Pages/Market.aspx

Olsthoorn, C.S., and Fong, N.P. 1998. The anthropogenic nitrogen cycle in the Netherlands. Nutrient Cycling in Agroecosystems 52:269-276

Petrovic, B. 2014. Environmental Accounting: Module Material Flow Accounts. Timeline 1995-2012. Statistik Austria (in German)

Pierer, M., Winiwarter, W., Leach, A.M., and Galloway, J.N. 2014. The nitrogen footprint of food products and general consumption patterns in Austria. Food Policy 49:128-136

Plastemart 2007a. Global scenario of polyamide looks quite challenging. Retrieved April 2013, from http://www.plastemart.com

Plastemart 2007b. Special polyamides are expected to grow much faster than polyamide 6 \& 6.6. Retrieved Mai 2014, from http://www.plastemart.com

Raimar, J. 2012. BASF's Polyurethanes Division Driving efficiency, comfort and sustainability. Presentation slides from the BASF Investor Day Automotive 5 Sep 2012., from http://www.basf.com/group/corporate/en_GB/function/conversions:/publish/content/investorrelations/calendar/images/120905/BASF_Investor_Day_Automotive_Polyurethanes.pdf

Saikku, L., Antikainen, R., and Kauppi, P.E. 2007. Nitrogen and Phosphorus in the Finnish Energy System, 19002003. Journal of Industrial Ecology 11(1):103-119

Smil, V. 2002. Nitrogen and Food Production: Proteins for Human Diets. Ambio 31(2):126-131 
Souci, S.W., Fachmann, W., Kraut, H., and Kirchhoff, E. 2008. Food composition and nutrition tables. On behalf of the Bundesministerium für Ernährung, Landwirtschaft und Verbraucherschutz, 7th edn. MedPharm Scientific Publishers; CRC Press, Stuttgart, Boca Raton, FL

Spiertz, J. 2010. Nitrogen, sustainable agriculture and food security. A review. Agronomy for Sustainable Development 30(1):43-55

Statistik Austria 2011. Overall consumption of fuels 2009/2010 in Gigajoule

Statistik Austria 2012a. Foreign trade of Austria 2012, DVD

Statistik Austria 2012b. Supply Balance Sheets

Stehfest, E., van den Berg, M., Woltjer, G., Msangi, S., and Westhoek, H. 2013. Options to reduce the environmental effects of livestock production - Comparison of two economic models. Agricultural Systems 114:38-53

Sutton, M., Dragosits, U., Tang, Y., and Fowler, D. 2000. Ammonia emissions from non-agricultural sources in the UK. Atmospheric Environment 34(6):855-869

Sutton, M.A., Howard, C., Erisman, J.W., Billen, G., Bleeker, A., Grennfelt, P., van Grinsven, H., and Grizzetti, B. 2011. The European Nitrogen Assessment. Sources, Effects and Policy Perspectives. Cambridge University Press, Cambridge/UK

Uihlein, A., Poganietz, W.-R., and Schebek, L. 2006. Carbon flows and carbon use in the German anthroposphere: An inventory. Resources, Conservation and Recycling 46:410-429

Umweltbundesamt 2012. Inventory of waste management in Austria. Status report 2012 (in German)

UN ECE 2013. Guidance document on national nitrogen budgets

van Egmond, K., Bresser, T., and Bouwman, L. 2002. The European Nitrogen Case. Ambio 31(2):72-78

van Grinsven, H.J.M., Holland, M., Jacobsen, B.H., Klimont, Z., Sutton, M.A., and Willems, W.J. 2013. Costs and Benefits of Nitrogen for Europe and Implications for Mitigation. Environmental Science \& Technology 47(8):3571-3579

Vaughan, S.M., Dalal, R.C., Harper, S.M., and Menzies, N.W. 2011. Effect of fresh green waste and green waste compost on mineral nitrogen, nitrous oxide and carbon dioxide from a Vertisol. Waste Management 31(8):1720-1728

Weiss, J., Maeß, J., and Nebendahl, K. 2003. Haus- und Versuchstierpflege, 2nd edn. Enke, Stuttgart (Pet care and care for experimental animals, in German) 


\section{Highlights}

National nitrogen (N) budgets usually focus on food and other agricultural products.

We investigate frequently neglected flows of nitrogen related to consumers.

Food consumed (and human excretion) account for over half of the $\mathrm{N}$ flows in 2010.

Non-food industrial products account for $28 \%$ of consumer $\mathrm{N}$ flows in Austria.

More complete nitrogen budgets need to consider non-food consumer-related aspects. 